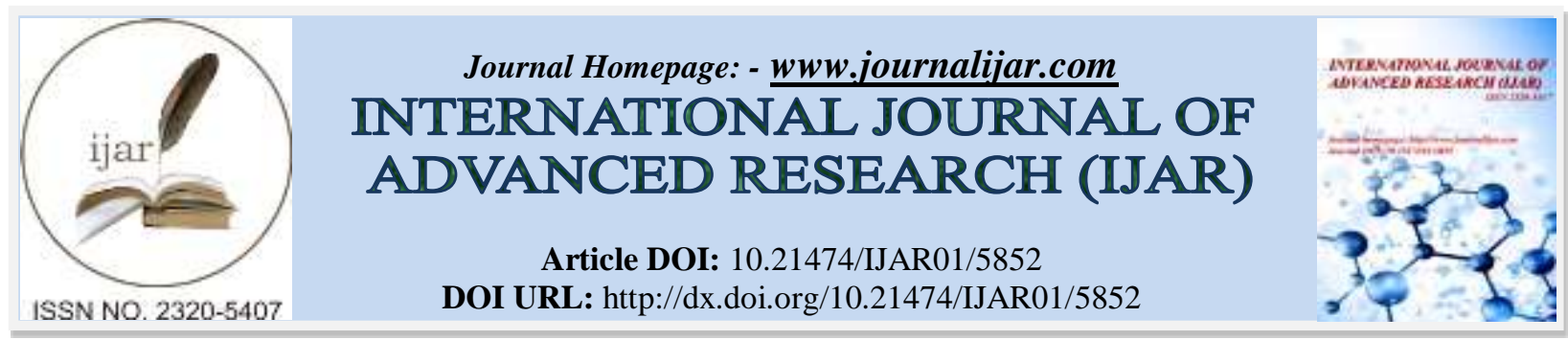

RESEARCH ARTICLE

\title{
A STUDY ON EFFECTIVENESS OF EMPLOYEE GRIEVANCES HANDLING MECHANISM IN TERTIARY CARE HOSPITALS IN COCHIN.
}

\author{
Mr. Deenathayalan Aruchamy ${ }^{1}$, Prof. M. Mariappan ${ }^{2}$ and Prof. Sasmita Palo ${ }^{3}$. \\ 1. Head - Operations Aster Medcity Cochin, Kerala India. \\ 2. Chairperson Centre for Hospital Management School of Health System Studies Tata Institute of Social Sciences \\ (TISS) Deonar, Mumbai India. \\ 3. Professor Centre for Labour studies School of Management and Labour studies Tata Institute of Social Sciences \\ (TISS) Deonar, Mumbai India.
}

\section{Manuscript Info}

\section{Manuscript History}

Received: 13 September 2017

Final Accepted: 15 October 2017

Published: November 2017

Key words:-

Grievance management, performance management, working environment, human relations.

\begin{abstract}
Employee grievances transpire in each \& every workplace. To handle the grievances was a very big and challenging task and that too it was very common in hospital industry due to its nature of stressful job. It was very important to understand how grievances were handled in hospital industry and also what was the process followed in managing the grievances. Grievance may be of any kind of dissatisfaction with regard to pay, promotion, suspension, working condition etc. This study focused on understanding the effectiveness of Grievance Handling Mechanism in tertiary care hospitals in Cochin from the perspective of employees. The objective of the study was to find the effectiveness of grievance handling mechanism being followed in hospitals in Edapally jurisdiction of Cochin. Questionnaire was the tool to collect the data from employees and convenience sampling is used to select the samples for the study. The sample size was 173 and the tools used for analyzing the responses were frequency distribution and percentage analysis. The study outcome revealed that grievance management system followed in hospitals is very effective and most of the employees were highly satisfied with the grievance management mechanism being followed.

Copy Right, IJAR, 2017, All rights reserved.
\end{abstract}

\section{Introduction:-}

Grievance is any discontent or dissatisfaction that affects organizational performance. As such it can be stated or unvoiced, written or oral, legitimate or ridiculous. If the dissatisfaction of employees' goes unattended or the conditions causing was not corrected, the irritation was likely to increase and lead to unfavorable attitude towards the management and unhealthy relations in the organization. The grievances of the employees were related to the contract, work rule or regulation, policy or procedure, health and safety regulation, past practice, changing the cultural norms unilaterally, individual victimization, salary etc. Here, the attitude on the part of management in their effort to understand the problems of employees and resolve the issues amicably have better probability to maintain a culture of high performance. Effective grievance handling is an essential part of cultivating good employee relations and running a fair, successful and productive workplace. The formal mechanism for dealing with such worker's dissatisfaction is called grievance procedure. The primary value of grievance procedure is that it can assist in 
minimizing discontent and dissatisfaction that may have adverse effects upon co-operation and productivity. Grievances were very natural in organizations. However there is a need for handling or redressing grievances. For this, most of the large organization in India has evolved a formal grievance procedure which enables an organization to handle grievances satisfactorily. As a matter of fact, there were are several substantive reasons for having a formal grievance procedure in an organization.

1. It provides an established and known method of processing grievances.

2. It brings grievance to the knowledge of management so that it can know and understand them to take necessary action for their settlement

3. It gives an assurance to the employee that there is a mechanism available to consider his or her grievance in a dispassionate and detached manner.

4. Venting his / her grievance and being heard gives the employee a feeling of being cared for. This not only gets it off his chest", but also helps him improve his morale and productivity.

5. Involvement of various levels makes them know the kinds of issues that concern workers and managers facing.

6. Lastly, it checks the managers from taking arbitrary and biased actions against the workers as they know that their actions are subject to challenge.

The basic factors for grievance management were timely action, accepting the grievance, identifying the problem correctly, collecting the facts, taking decision and implementing the decision. The grievances for the employees may be arising out of working condition (poor physical condition, non-availability of proper tools and machines etc.), arising out of management policy (salary, seniority, transfer etc.), arising out of alleged violation (rules and regulations, responsibilities etc.), arising out of personal maladjustment (over ambition, excessive self esteem etc.) and arising out of general conditions (disciplinary, medical benefits, leave etc.). The grievance identifying techniques were direct observation, suggestion boxes and easy and open access policy and exit interviews.

\section{Review of Literature:-}

Wyman (1971) stated in his study that the grievance procedure has been aptly described as the "heart of the collective bargaining process". Collective negotiations, of course normally result in a written agreement. However, an agreement is a static document presumably intended to cover all aspects of labor management relations, a task that no document can accomplish completely. Gordon, M.E. and Miller, S. (1984) stated in his study that the issues of grievances were normally associated with dissatisfaction among employees which were mainly related to salary, working procedure and working facilities. Dr. Nilesh Thakre (2013) stated in his study about resolving grievances, aggrieved employees will file their dissatisfaction through grievance procedure and their immediate managers or supervisors were responsible to take action within period given. Therefore, immediate supervisors were responsible to settle the grievance as they were the nearest personnel that represent managerial team, thus the result of the study is that the argument on the vital role played by supervisors in managing employees' grievances paralleled that of past studies. Pawan Kumar Taneja and Singh P.P, (2004) in their study argued that evaluations of grievance procedure effectiveness should include subjective evaluations by the participants as well as objective measures reflecting the operation of the grievance procedure. They argued that subjective evaluations are the preferred method for evaluating grievance procedure effectiveness.

\section{Statement of research problem:-}

Grievances were very common in all the industry and it might be for pay, promotion, suspension, working condition etc. In hospitals, grievances were very common because of its nature of stressful job and also very big challenge to handle. But hospital industries were also taking great effort to handle the grievances. But it was very important to evaluate the grievance process in hospitals to understand its impact. Hence there would be need for a study to understand how grievances were handled in hospital industry, whether considered all the employee grievances and also what was the process followed in managing the grievances.

\section{Objectives of the study:-}

1. The aim of the study is to find whether the grievance handling mechanism identifies that the employee's problems were recognized and appropriately reviewed in a prompt and timely manner.

2. To identify whether grievance mechanism ensures a fair treatment of employee's concerns and prompt resolution of grievances without discrimination, coercion, restraint or reprisal against any employee who may submit or be involved in a grievance. 


\section{Research Methodology:-}

Nature of this study was descriptive, as the main purpose of this study was to gain more knowledge about the level of grievance handling among the employees in the hospitals. Primary data collection was through questionnaire method wherein the questionnaire was handed over to the respondents and the same were analyzed. The sample size was 173 and the tools used for analyzing the responses were frequency distribution and percentage analysis. Area of the study was hospitals in Edapally jurisdiction of Cochin.

Data Analysis:-

Table 1:- Demographic details.

\begin{tabular}{|c|c|c|c|c|}
\hline S.No. & Variables & Respondents & Frequency & Percentage \\
\hline 1 & Gender & Male & 98 & $57 \%$ \\
\hline & & Female & 75 & $43 \%$ \\
\hline 2 & Age & $<30$ yrs & 12 & $7 \%$ \\
\hline & & $31-40 \mathrm{yrs}$ & 63 & $36 \%$ \\
\hline & & $41-50 \mathrm{yrs}$ & 39 & $23 \%$ \\
\hline & & $>50$ Yrs & 59 & $34 \%$ \\
\hline 3 & Qualification & Schooling and Diploma & 18 & $10 \%$ \\
\hline & & Graduates & 73 & $42 \%$ \\
\hline & & Post graduates & 54 & $31 \%$ \\
\hline & & Doctorate & 28 & $17 \%$ \\
\hline 4 & Marital Status & Single & 33 & $19 \%$ \\
\hline & & Married & 140 & $26 \%$ \\
\hline & Work experience & $<10$ Yrs & 46 & $53 \%$ \\
\hline & & $11-20 \mathrm{Yrs}$ & 91 & $12 \%$ \\
\hline & & $21-30 \mathrm{Yrs}$ & 20 & $9 \%$ \\
\hline
\end{tabular}

\section{Interpretation:-}

From the above table, it was inferred that

1. $57 \%$ of employees were male and $43 \%$ of employees were female respondents for the study.

2. $7 \%$ of employees were less than 30 yrs of age and $34 \%$ were above 50 yrs of age and majority of the respondents were in $31 \mathrm{yrs}-40 \mathrm{yrs}$ of age group.

3. Only $10 \%$ of employees were having schooling and diploma as qualification and majority of $42 \%$ of employees were graduates.

4. $81 \%$ of respondents were married.

5. $53 \%$ of respondents were with $11-20 \mathrm{yrs}$ of experience and $9 \%$ of employees were more than 31 yrs of experience.

Table 2:- Grievance nature

\begin{tabular}{|c|c|c|}
\hline Grievances related to & Frequency & Percent \\
\hline Work environment & 19 & $11 \%$ \\
\hline Supervision & 33 & $19 \%$ \\
\hline Work group & 28 & $16 \%$ \\
\hline Economic (salary, reward, incentives) & 74 & $43 \%$ \\
\hline Social injustice \& others & 19 & $11 \%$ \\
\hline Total & 173 & $100 \%$ \\
\hline
\end{tabular}

\section{Interpretation:-}

From the above table, it was inferred that

1. $11 \%$ of grievances were related to work environment and social injustice and others.

2. $19 \%$ of grievances were related to supervision and $16 \%$ of grievances were related to work group.

3. Major grievance of $43 \%$ was related to economic requirement. 
Table 3:- Frequency of grievances

\begin{tabular}{|c|c|c|}
\hline Grievances Frequency & Frequency & Percent \\
\hline Mostly & 19 & $11 \%$ \\
\hline Rarely & 91 & $53 \%$ \\
\hline Sometimes & 63 & $36 \%$ \\
\hline Total & 173 & $100 \%$ \\
\hline
\end{tabular}

\section{Interpretation:-}

From the above table, it was inferred that

$53 \%$ of employees were responded that grievance occurring frequency was rare. $36 \%$ of employees were responded that grievance occurs sometimes and $11 \%$ were responded that it occurs mostly.

Table 4:- Primary sharing respondent of grievances

\begin{tabular}{|c|c|c|}
\hline Primary sharing respondent & Frequency & Percent \\
\hline Superior & 39 & $23 \%$ \\
\hline Colleagues & 103 & $60 \%$ \\
\hline HR or Management & 31 & $17 \%$ \\
\hline Total & 173 & $100 \%$ \\
\hline
\end{tabular}

\section{Interpretation:-}

From the above table, it was inferred that

1. $60 \%$ of employees were responded that grievance was primarily shared with colleagues only.

2. $23 \%$ of employees were responded that grievance was primarily shared with superior and $17 \%$ were sharing primarily with HR or management directly.

Table 5:- Time taken for grievance redressal

\begin{tabular}{|c|c|c|}
\hline Time taken for grievance redressal & Frequency & Percent \\
\hline$<2$ weeks & 101 & $58 \%$ \\
\hline$>2$ weeks & 53 & $31 \%$ \\
\hline Long pending with $>2$ Months & 19 & $11 \%$ \\
\hline Total & 173 & $100 \%$ \\
\hline
\end{tabular}

\section{Interpretation:-}

From the above table, it was inferred that

1. $58 \%$ of employees were responded that grievance was closed with 2 weeks of time.

2. $31 \%$ of employees were responded that grievance was closed with time duration of more than 2 weeks. $11 \%$ of employees were responded that grievance redressal was pending and it had crossed more than 2 months.

Table 6:- Level of satisfaction of grievance settlement

\begin{tabular}{|c|c|c|}
\hline Satisfaction of grievance settlement & Frequency & Percent \\
\hline Completely & 95 & $55 \%$ \\
\hline Certain extent to satisfactory & 59 & $34 \%$ \\
\hline Not at all & 19 & $11 \%$ \\
\hline Total & 173 & $100 \%$ \\
\hline
\end{tabular}

\section{Interpretation:-}

From the above table, it was inferred that

1. $55 \%$ of employees were responded that completely satisfied with grievance settlement.

2. $34 \%$ of employees were responded that certain extent to satisfactory with grievance settlement and $11 \%$ not at all satisfied with the grievance settlement.

Table 7:- Proper process, relevant fact finding, proper listening, transparent process followed in grievance redressal.

\begin{tabular}{|c|c|c|}
\hline Proper process, fact finding, proper listening & Frequency & Percent \\
\hline Strongly Agree & 74 & $43 \%$ \\
\hline Agree & 54 & $31 \%$ \\
\hline
\end{tabular}




\begin{tabular}{|c|c|c|}
\hline Don't know & 3 & $1 \%$ \\
\hline Disagree & 23 & $14 \%$ \\
\hline Strongly Disagree & 19 & $11 \%$ \\
\hline Total & 173 & $100 \%$ \\
\hline
\end{tabular}

\section{Interpretation:-}

From the above table, it was inferred that

1. $43 \%$ of employees were responded that they were strongly agree that proper process, relevant fact finding and proper listening was followed in grievance redressal. $31 \%$ were responded that they were agreeing that proper process was followed.

2. $11 \%$ strongly disagree and $14 \%$ disagree that proper process followed in grievance redressal.

Table 8:- Grievance redressal committee possess necessary skills to handle the issue

\begin{tabular}{|c|c|c|}
\hline Necessary skill to handle the issue & Frequency & Percent \\
\hline Highly skilled & 88 & $46 \%$ \\
\hline Moderately skilled & 71 & $41 \%$ \\
\hline Not skilled & 14 & $13 \%$ \\
\hline Total & 173 & $100 \%$ \\
\hline
\end{tabular}

\section{Interpretation:-}

From the above table, it was inferred that

1. $46 \%$ of employees were responded that grievance redressal committee was highly skilled to handle the issue.

2. $41 \%$ of employees were responded that grievance redressal committee was moderately skilled to handle the issue and $13 \%$ responded not skilled.

Table 9:- Grievance handling policy of your hospital is very effective

\begin{tabular}{|c|c|c|}
\hline Grievance handling policy is very effective & Frequency & Percent \\
\hline Strongly Agree & 79 & $46 \%$ \\
\hline Agree & 56 & $32 \%$ \\
\hline Don't know & 6 & $3 \%$ \\
\hline Disagree & 21 & $12 \%$ \\
\hline Strongly Disagree & 11 & $7 \%$ \\
\hline Total & 173 & $100 \%$ \\
\hline
\end{tabular}

\section{Interpretation:-}

From the above table, it was inferred that

1. $46 \%$ of employees were responded that they were strongly agreed that grievance handling policy is very effective. $32 \%$ were responded that they were agreeing that grievance handling policy is effective.

2. $7 \%$ strongly disagree and $12 \%$ disagree that grievance handling policy is very effective.

\section{Findings:-}

1. Major grievance in hospital were relating to economic factor such as salary, reward, increment, incentives etc.

2. Most of the employees responded that grievance occurring frequency was rare.

3. Most of the employees were responded that grievance was primarily shared with their colleagues only.

4. Most of the employees were responded that grievance was closed with 2 weeks of time.

5. Most of the employees were responded that completely satisfied with grievance settlement.

6. Most of the employees were responded that they were strongly agree that proper process, relevant fact finding and proper listening was followed in grievance redressal.

7. Employees felt that grievance redressal committee was skilled to handle the issue.

8. Employees felt that grievance handling policy is very effective in hospital.

\section{Recommendations:-}

1. Need to incorporate technology based grievance raising mechanism to make the process simpler, confidential and employee friendly. 
2. HR has to meet all the department and employees in periodical basis to get the feedback and existence of any issues.

3. More awareness and training to be provided to employees on grievance procedures and policy.

4. HR and management must take responsibility in closing all the grievances at the very earliest to ensure employee feel confidence on the grievance redressal process.

5. Supervisors in the department were trained to handle the grievances of employees in proper manner and also to come out with optimum solution as recommendation to management for solving the grievances permanently.

\section{Conclusion:-}

Hospitals in Edapally jurisdiction of Cochin is effectively progressed in a systematic way of working process in the organization and every data or transactions handling with the patients, employees are pre-planned so there was a very less chance for risk factors or any unexpected happenings like grievances. Hospital also taken steps to rectify the grievances at the earliest based on the policy formulated. A balanced workflow is been followed throughout the hospital which leads to an effective coordination among the employees in the hospital. HR department also meets the need of every employee's directly and brings them a positive result as soon as possible by taking the right action. Overall, the study outcome revealed that grievance management system followed in hospitals is very effective and most of the employees were highly satisfied with the grievance management mechanism being followed.

\section{References:-}

1. Wyman 1971, B. S. Klaas \& Thomas 1994 (ed.), International Encyclopedia of grievance and human Administration, Vol. 1: A 2000.

2. Gordon, M.E. and Miller, S. 1984. "Grievances: A Review of Research and Practice", Personnel Psychology, 37(1): 117-46.

3. Dr. Nilesh Thakre, Employee Grievance Redressal Procedure in Indian organizations, IJRCM, 2013, Vol 3 (4), pg 98-102

4. Pawan Kumar Taneja and Singh P.P, (2004).Capital Market Reforms- A Case Study of Grievances and Awareness of Retail Investors in Stock Market. New Delhi: Deep and Deep Publication. ISBN: 81-7629-724-0, 20-30.

5. http://www.ijcrm.com/

6. http://www.theijbm.com/

7. http://www.ijemr.com/ 